\title{
Tarımda Kalma Eğilimini Etkileyen Başlıca Faktörlerin Genel Bir Değerlendirmesi
}

Oya SAV1 Cengiz SAYIN

Akdeniz Üniversitesi, Ziraat Fakültesi Tarım Ekonomisi Bölümü, Antalya

$\bowtie$ : csayin@akdeniz.edu.tr

\section{ÖZET}

Tarım sektörü başta toplumun gıda ihtiyacının karşılanması olmak üzere istihdam, ihracat, yatırım, hammadde temini ve katma değer yaratma gibi ekonomik katkıları nedeniyle tüm ülkelerde önemini her zaman korumaktadır.Türkiye'de de tarım sektörü belirtilen tüm konulardaki önemini baskın bir şekilde sürdürmektedir. Ancak gelinen noktada, taşıdığı bu öneme karşın, tarımda giderek yaşlanan ve tarım dışına kayan bir üretici sorunu yaşanmaktadır. Bir yandan tarımda kalma öte yandan kente göçü alternatif olarak görme seçenekleri genç tarım üreticilerini ve adaylarını tercih yapmada bir hayli zorlamaktadır. $\mathrm{Bu}$ durum, ülke tarımının geleceği ve sürdürülebilirliği açısından olumlu sinyaller vermemektedir. Çiftçi kararlarının ve davranışlarının; ekonomik, sosyal, kültürel, politik, coğrafi ve psikolojik olmak üzere oldukça çeşitli faktörlerden etkilendiği iyi bilinmektedir. Bu bakımdan üreticilerin "tarımda kalma" ya da "kalmama" eğilimlerine neden olan temel faktörlerin doğru belirlenmesi; geleceğe yönelik gıda güvencesi ve tarımın sürdürülebilirliğinin sağlanması, kırsal alanların sosyo-ekonomik devamlılığının sağlanması açısından son derece önemli görülmektedir. İkincil verilerden yararlanılan bu çalışmada, çiftçilerin tarımsal faaliyeti sürdürme ya da faaliyete devam etmeme eğilimlerinin tartışılması amaçlanmıştır. Tarımın çok boyutluluğu göz önüne alınarak geniş bir çerçevede üreticilerin tarımdan ayrılma nedenleri incelenerek çözüm yollarının aranması, tarımsal üretim yeterliliği ile ülke refahı ve kalkınma yolunda büyük bir adım olacaktır.
Makale Tarihçesi

Geliş : 21.10.2018

Kabul : 27.12.2018

Anahtar Kelimeler
Kalma Eğilimi,
Tarım,
Sürdürülebilirlik,
Destekleme Araçları,
Faktörler.

\section{Derleme Makalesi}

\section{General Assessments of Main Factor Affecting Tendency to Stay in Agriculture}

\section{ABSTRACT}

The agriculture sector always maintains its importance in all countries mainly due to its economic contributions to the components such as employment, export, investment, raw material creation and creation of value added, especially in meeting the food needs of the society. Also, agricultural sector in Turkey continues its importance in all matters referred predominantly. However, at this point, despite the importance, there is a aging producer problem in agriculture causing them moving away from agriculture. On the other hand, the choice of agriculture or urban migration as alternatives makes it very difficult for young agricultural producers or candidates to choose. This issue does not give positive signals for sustainability of the country's agriculture in the future. As it is known that farmer's decisions and behaviours are influenced by several factors such as economic, social, cultural, political, geographical and psychological factors. In this respect, the correct determination of the basic factors that cause the producers' tendency to "stay" or "not stay" in agriculture is vey important for the future food security and ensuring sustainability of agriculture in terms of ensuring the socio-economic sustainability of rural areas. In this study, it is aimed to discuss the tendency of farmers to maintain or not to continue agricultural activity by using

\section{Article History}

Received : 21.10.2018

Accepted : 27.12.2018

\section{Keywords \\ Tendency To Stay, \\ Agriculture, \\ Sustainability, \\ Support Tools, \\ Factors.}

\section{Review Article}


secondary data. Taking into consideration the multidimensionality of agriculture in a wide frame, examining the reasons of farmers for leaving the agriculture will be a big step towards the welfare and development of the country with its agricultural production adequacy.

To cite: Sav O, Sayın C 2018. Tarımda Kalma Eğilimini Etkileyen Başlıca Faktörlerin Genel Bir Değerlendirmesi. KSÜ Tar Doğa Derg 21(Özel Sayı) : 190-197, DOI : 10.18016/ ksutarimdoga.vi.472890

\section{GIRIŞ̧}

Türkiye ekonomisinde tarım sadece bitkisel ve hayvansal üretim faaliyeti olarak değil; istihdam, gıda, yurt içi tüketim, sanayiye katkı, milli gelir ve dış ticaret açısından da uzun vadeli politikalar ile ele alınması gereken bir sektördür. Tarımsal üretimde zaman zaman yaşanan dalgalanmalar sektörde istikrarsızlığa neden olurken yaşanan sorunlar, tarıma ekonomik, sosyolojik ve politik çerçevede yansımaktadır. Oysaki talebe uygun planlı üretim ile ürünlerde arz fazlası sorunu çözülerek üretici fiyatlarındaki düşüşün önüne geçilebilir ve yine bazı ürünlerde oluşan arz açığı sorunu da ortadan kaldırılarak büyük ölçüde ithalat ödemeleri azaltılabilir. Çünkü bilinmektedir ki plansız üretim modelleri, üretici mağduriyeti oluştururken üreticinin bitkisel ya da hayvansal üretim faaliyetinden vazgeçmesine neden olmaktadır.

Sürdürülebilirlik, sistemin kendini uzun vadede devam ettirebilmesi için ekolojik, ekonomik, sosyal ve kültürel açıdan yeniden üretmesi olarak algılanmaktadır. Sürdürülebilir tarım ise, çevreyi ve doğal kaynakları koruyarak yeterli ve güvenilir gıdanın üretilmesi olarak ifade edilebilir. Tarımsal faaliyeti bırakma ve kırsal göç ise kırsal alanlarda yaşayan insanların yeni yaşam alanlarına taşınması olup daha çok kırdan kente sanayi bölgelerine doğru olmaktadır. Türkiye'de tarımda giderek yaşlanan, köyden kente göçen ve tarım dışına kayan bir üretici sorunu yaşanmaktadır. Yaşanan bu durum ile Türkiye tarım ülkesi olma özelliğini gün geçtikçe yitirmektedir. Göç eden nüfusla beraber tarımsal üretimde oluşan azalma Türkiye'de bugün birçok ürünün ithal edilmesine sebep olmaktadır. $\mathrm{Bu}$ durum, ülke tarımının geleceği ile arz ve fiyat kapsamında tarımın sürdürülebilirliği diğer bir ifade ile üreticilerin tarımda kalıp üretime devam etmeleri açısından kaygı verici bir sonuç doğurmaktadır. Üreticinin tarımı bırakması ile tarımsal alanlarda kaynak israfı olmakta, erozyon yaşanmakta, gida güvencesi sorunu ortaya çıkmakta, boşalan araziler amaç dışı kullanılarak doğal kaynaklar hızla yok olmaktadır.

Tarımda sürdürülebilirlik ve göç ilgili yapılan daha önceki çalışmalarda konunun daha çok çevresel sürdürülebilirlik yönüyle ele alındığı, tarımsal faaliyetlere ilişkin davranış ve tutumlarının incelendiği çalışmaların sayısının sınırlı olduğu görülmektedir. Uysal (2015), Manisa İli Yunt Dağı'nda yaptığı çalışmada üreticilerin çiftçilikten çok memnun olmadığı ve büyük bölümünün çiftçilik mesleğinden "vazgeçebilecekleri" yönünde bulgular elde etmiştir. Çukur'a (2016) göre organik tarım hakkında bilgi sahibi olmanın çiftçilerin tarımda kalma eğilimleri üzerinde pozitif; tarım dışı gelire sahip olmanın ise çiftçilerin tarımda kalma eğilimleri üzerinde negatif bir etkisi bulunmaktadır. Yavuz ve Özüdoğru (2015), üreticilerin tarımsal üretimlerini sürdürebilmek için gerekli gördükleri en önemli koşulu "İyi fiyat" olarak belirlemiştir. Bezu ve Holden (2014), kırsaldaki gençlerin sadece \%6'sının tarımsal faaliyeti sürdürmek istediklerini çalışmalarında ortaya koymuşlardır. Çukur ve Işın (2008), üreticinin \%50.82'sinin gelecekte tarıma devam etmeyi düşünmediklerini belirlemişlerdir. Çelik (2017), Samsun ili Çarşamba ilçesinde çocuklarının çiftçilik mesleğini devam ettirmesini isteyenlerin oranını \%33,9 olarak hesaplanmıştır. Fidan (2017), Bartın ilinde gerçekleştirdiği çalışmada çiftçilerin \%83’ünün ileride organik üretime devam edeceğini, tarımın sürdürülebilirliğinin çiftçilerin bu ürünlerden elde ettiği yıllık gelirlere bağlı olduğu sonucunu ortaya koymuştur. Yıldız (2015), Ege bölgesinde yaptığı çalışmada üreticilerin \%78.52'sinin çocuklarının veya yakınlarının gelir düşüklüğü ve işlerin ağır olması nedeniyle çiftçilik yapmasını istemediğini aktarmıştır. Arlı ve ark. (2014), Akhisar'da gençlerin çiftçiliği tercih etmemelerinde tarımsal gelir düzeyinin düşük olmasını en önemli faktör, kırsal alandaki yaşam koşullarını ise en az önemli faktör olarak belirlemiştir. Cengiz ve Baydur (2010) olumsuz iç ticaret hadleri ve yatırımların tarımsal istihdam üzerindeki etkisinin sinırlı olması nedeniyle tarımsal ücretler artsa bile bu artışın çok düşük olmasından dolayı kırdan kente göçün devam edeceği sonucuna ulaşmışlardır. Yalçın ve Kara (2016) kırdan kente göçün nedenlerini ve tarımsal üretime etkilerini araştırmış olup sorunların çözümüne yönelik öneriler getirmişlerdir. Gürbüz ve Karabulut (2008), kırsal göçün, sosyo-ekonomik verilerden büyük ölçüde etkilendiğini ortaya koyarken şehirlerin çekici özellikleri gibi ölçülemeyen bazı sosyo-psikolojik faktörlerin göç üzerinde etkileyici olduğunu belirlemişledir. 
Günümüzde olduğu gibi gelecek yıllarda da Türkiye'de ana geçim kaynağı olarak tarımsal faaliyeti sürdüren genç üreticilere şiddetle ihtiyaç bulunmaktadır. Nitekim benzer sorun geçmişte Avrupa Birliği'nde(AB) de yoğun bir şekilde yaşanmış ancak gereken tarımsal destekleme önlemlerinin zamanında alınmış olmasına karşın bu sorun henüz tam olarak çözüme kavuşturulamamıştır. Şöyle ki AB'de mevcut tarım işletmelerinin sadece \%6'sının 35 yaşın altındaki bireyler tarafindan işletilmesi, tarım sektörünün gençler tarafından tercih edilmediğini göstermektedir. Yaşlanan tarımsal nüfusa çözüm bulmak, gelecekte gıda arzının devamlılığını sağlamak, AB'nin tarımdaki rekabetçi konumunun devamlılığını sağlamak ve gençleri tarıma çekmek için AB Ortak Tarım Politikası kapsamında doğrudan ödemelere ve kırsal kalkınma programlarına ek olarak ulusal-bölgesel kalkınma planlarının AB'de uygulandığı görülmektedir (Anonim, 2017a).

$\mathrm{Bu}$ çalışmada; ülkemizde tarımsal faaliyet gerçekleştiren çiftçilerin tarımsal faaliyeti sürdürme ve tarımı bırakıp başka sektörlere yönelme eğilimlerinin nedenlerinin ve sonuçlarının, izlenen destekleyici politikalar kapsammda irdelenmesi amaçlanmıştır.

\section{MATERYAL ve METOT}

Çalışmanın ana materyalini ikincil veriler oluşturmaktadır. Temel kaynaklar olarak; Tarım ve Orman Bakanlığı, Türkiye İstatistik Kurumu (TÜİK), çeşitli bilimsel araştırmalar, raporlar, tezler ve makaleler kullanılmıştır.

İkincil veri kaynaklarına, konuyla ilgili olarak uzmanlarla yapılan "görüşme cetveli" ve "ön değerlendirme anketi" bulgularına dayanılarak; öncelikle tarımsal faaliyet sürdüren üreticilerin faaliyette kalma eğilimlerinin belirlenmesinde etkili olabilecek faktörlerin gruplandırılması yapılmış, daha sonra bu kapsama giren başlıca alt değişkenlerin neler olabileceği mevcut veri kaynaklarından karşılaştırmalı durum analizine dayanılarak belirlenmeye çalışılmıştır.

\section{BULGULAR ve TARTIŞMA}

\section{İzlenen Tarımsal Destekleme Politikalarına Bakış}

Türkiye'de serbest piyasa ekonomisine 1980'lerde geçis sonrasında devletin tarıma müdahalelerin azaltılması ile destekleyici politikalardan uzaklaşılmış. Fiyat destekleme politikaları, girdi destekleri, düşük faizli kredi temini gibi müdahaleler azaltılmış ve tarımsal amaçlı KİT’ler özelleştirilmiş. Desteklenen ürünlerin kapsamı hububat, şeker pancarı ve tütün olarak Nisan 1994 tarihinde alınan kararlarla daraltılmıştır. Dünya Ticaret Örgütü Tarım Anlaşması, AB Ortak Tarım Politikası, IMF ve Dünya Bankası politika önerileri kapsamında 2000'li yıllardan sonra destekleme alımları azaltılmıs, destekleme fiyatları düşürülmüş, piyasa ekonomisinin güçlendirilmesi hedeflenmiş ve desteklerin üreticiye doğrudan ödemeler yoluyla verilmesi sözkonusu olmuştur (Sayın, 2003).

Tarımsal desteklemelerin amacı 2006 yılında çıkartılan 5488 sayılı Tarım Kanunu'nda "tarım sektörünün öncelikli problemlerinin çözümüne katkıda bulunmak, uygulanan politikaların etkinliğini artırmak, sektörün bu politikalara uyumunu kolaylaştırmaktır" şeklinde ifade edilmiştir. Günümüze geldiğinde 2017 yılında verilen desteklemelerden, Türkiye Tarım Havzaları Üretim ve Destekleme Modeli kapsamında Çiftçi Kayıt Sistemi'ne kayitlı olan ve belirlenen havzalarda yer alan, desteklemeye tabi ürünleri ürettiği belirlenen ve yasal süre içerisinde destekleme başvurularını yapan gerçek ve tüzel kişiler yararlanmaktadır. Bakanlıkça 2017 yllinda toplamda 7,7 milyon TL destekleme ödemesi yapılmıştır. Alan bazlı tarımsal destek ödemelerinin destekleme bütçesindeki payı 2017 yll itibariyle \%33 iken fark ödemesi \%50'dir (TOB, 2018).

Bakanlık, tarımsal üretiminde üreticiyi desteklemek adına başta agronomik ürünler, baklagiller ile soğan, yaş çay, fındık, yem bitkiler olmak üzere seçili ürünlere değişen değerlerde mazot desteği uygulanmaktadır. Diğer yandan desteklenen ürünlerin havza dışında yetiştirilmesi durumunda belirlenen ürünlere mazot, gübre ve fark ödemesi desteği verilmeyeceği açıklanmıştır. Bunun yanısıra toprak analizi, organik tarım ve iyi tarım uygulamaları ile alan bazlı gelir desteği, fark ödemesi, yurt içi sertifikalı tohumluk ve fidan desteği verilmektedir. Zeytinciliği korumak adına geleneksel zeytin bahçelerinin rehabilitasyonu desteği kapsamında dekar başına Bakanlık tarafından ödeme yapılmaktadır.

Bakanlık tarafindan hayvancılık ile uğraşan üreticileri desteklemek amacı ile yem bitkileri üretim desteği ile bombus arısı, küçükbaş ve büyükbaş yetiştiricilerine hayvan başına ödemeler ile destek verilmesi sağlanırken bunlara ek olarak çoban istihdam desteği de verilmektedir. Bu desteklere ek olarak Bakanlık, ürettiği çiğ sütü kayıtlı süt işleme tesislerine satan ve bir hayvancılık örgütüne üye olan yetiştiricilere çiğ süt desteklemeleri ile arı ve ipek böceği yetiştiricilerine çeşitli miktarlarda destek uygulamaktadır. Su ürünleri desteği çerçevesinde alabalık, midye gibi ürünlere destek sağlanırken 
geleneksel kıyı balıkçılığının devamlılığı için 10 metreden küçük balıkçı gemilerine de destek verilmektedir.

Örgütlenmeyi teşvik etme amacıyla ziraat odası ve üretici örgütlerine, istihdam edilen tarım danışmanı için tarımsal yayım ve danışmanlık desteği verilmektedir. Bitkisel üretim yapan küçük aile işletmelerinin desteklenmesi uygulamaları kapsamında dekar başına ödemeler yapılmaktadır. Türkiye'de, özellikle gençler için tarım sektörünü çekim merkezi haline getirmek adına 2017'de 16 bin 67 genç çiftçiye 30'ar bin TL'lik hibe desteği sağlanmıştır. $\mathrm{Bu}$ kapsamda Genç Çiftçi Projesi kapsamında 2017 yılında 3.463 proje ile dağıtımı yapılan küçükbaş sayısı 128.131 adet iken 8.544 proje ile büyükbaş sayısı 51.095 adet olmuştur. Destek ihtiyacının \%75'inden fazlasının hayvancılık alanından geldiği, kalanın ise arıcılık, kanatlı ve ipekböcek yetiştiriciliği, bağcılık ve kapama meyve bahçesi, mantar üretimi tesisi, örtü altı ve fide-fidan süs bitkisi üretimi tesisi ve tıbbi aromatik ve coğrafi işaretli ürünler alanlarında uygulandığı ifade edilmiştir (TOB, 2018).

Tarım Yasası'na göre Gayri Safi Milli Hasıla'nın en az yüzde 1'inin tarıma destek olarak verilmesi öngörülmektedir. Ancak yasaya rağmen bu oran yakalanamamaktadır. Diğer yandan destekleme ödemelerinin beklenen sonucu doğurması için üretim maliyetlerinin incelenerek ürün seçiminin yapılması ve verilecek desteklerin etkilerinin analiz edilmesi gerekmektedir.

Frankfurt School of Finance and Management GmbH tarafindan Akdeniz, İç Anadolu, Karadeniz, Ege bölgelerinden 986 ilçede yapılan 2017 Türkiye Tarımsal Desteklemeler Saha Araştırması sonuçlarına göre üreticilerin \%90.13'ü tarımsal hibe ve destekler olmaz ise tarımsal üretim veya yatırımından vazgeçmeyeceğini belirtmiştir. Buna ek olarak tarımsal hibe ve destekler olursa üretim yapacaklarını ifade edenlerin oranın anket gerçekleştirilen üreticiler içinde $\% 9.8$ olması tarımsal hibe ve desteklemelerin, tarımsal üretim ve yatırımların sürdürülebilirliğinde etkisinin olmadığını göstermektedir (Anonim, 2018a).

\section{Türkiye'de Makroekonomik Göstergeler ve Tarımın} Önemi

Bu kısımda oluşturduğu üretim değeri, ihracat ve istihdam kapsamında makroekonomik göstergeler açısından tarımın değeri Türkiye'de ele alınmıştır. Makro ekonomik göstergeler açısından tarımın GSYH ve istihdam içerisindeki payı giderek azalmaktadır. Oranlara göre Cumhuriyet'in ilk yıllarında cari fiyatlarla tarımın GSYH'daki payı \%42.8 iken 1970'li yıllarda \%36, 1985 yılında \%25, 1990 yılında \%16.0, 2000 yılında \%13.5, 2010 yılında \%10 oraninda gerçekleşmiştir. En son olarak 2017 yılında 851 milyar dolar olarak gerçekleşen GSYH'nın \%6'sını (52 milyar dolar) tarım sektörü oluşturmaktadır, tarımın ihracattaki payı \%10.8 (17milyar\$), ithalattaki payının \%2.1'dir (5 milyar\$) (TÜIK, 2018). Tarım 2010 yılında bir önceki yıla göre \%28.9 büyürken 2013 yılında gelişim kaydetmemiştir. İlerleyen yıllara bakıldığında tarımın 2014 yılında $\% 10$ büyüdüğü görülürken 2016 yılında ise tarım \%0.1 küçülmüştür. Tarımsal değer, 2010 yılında 104 milyar TL iken 2017 yılında bir önceki yıla göre \% 16.9 artışla 188,6 milyar TL olarak gerçekleşmiş̧ir. Buna göre son 10 ylllık süreçte tarımsal gelirin dalgalı bir seyir izlediği görülmektedir (Çizelge 1).

Çizelge 1. Tarımsal gelir ve değişim oranı

\begin{tabular}{ccc}
\hline Yıllar & $\begin{array}{c}\text { Tarım } \\
\text { (Bin TL) }\end{array}$ & $\begin{array}{c}\text { Önceki Ylla Göre } \\
\text { Değişim Oranı }\end{array}$ \\
\hline 2009 & 81.234 .274 & 9,1 \\
2010 & 104.703 .635 & 28,9 \\
2011 & 114.838 .169 & 9,7 \\
2012 & 121.692 .893 & 6,0 \\
2013 & 121.709 .079 & 0,0 \\
2014 & 134.724 .745 & 10,7 \\
2015 & 161.447 .917 & 19,8 \\
2016 & 161.304 .618 & $-0,1$ \\
2017 & 188.650 .644 & 17,0 \\
\hline
\end{tabular}

Kaynak: TÜİK, 2018.

İstihdam boyutunda ise 2007 yılında çalışanların \%22.5’i tarım sektöründe çalışırken bu oran 2017 yılında \%19.4'e gerilemiştir. Türkiye'de 2017 yılı itibariye 28 milyonu geçen çalışanın yaklaşık 5 milyonu tarım sektöründe çalışmaktadır (TÜİK, 2018). Bilinmektedir ki tarım sektöründe çalışanların bir bölümü başka sektörlerde iş bulabildikleri anda tarım sektörünü terk etmekte ancak, ekonominin küçüldüğü dönemlerde tekrar tarım sektörüne dönmektedirler. Günümüzde Türkiye'de 20 milyon dolayında kırsal nüfus bulunurken TÜİK temel projeksiyonuna göre 2026 'da 16,7 milyona, 2034 'de $1, .2$ milyona, 2042'de 9 milyona, 2050'de 4,5 milyona gerileyecektir. Çiftçi Kayıt Sistemi'ne kayıtlı olan çiftçi sayısı 2002 yılında 2.588.666 iken 2017 yılı itibariyle 2.132.491'e düşmüştür. Üretim yapılan alan ise bu 15 yıl içerisinde 164 milyon dekardan 148 milyon dekara inmiştir. Üretimde kullanılan girdiler incelendiğinde mazot fiyatı yıllık ortalaması 2002 yılında litre başına 1,09 TL iken 2017 yılında 4,70 TL'ye ulaşmıştır. Yine üretimde kullanılan ve ithal edilen kimyevi gübre fiyatlarında ise gübre cinslerine göre değişmekle 
beraber \%200 ile \%400 arasında değişen oranlarda artı̧̧ yaşanmıştır (TOB, 2018). Maliyetlerde gözlenen bu veriler Türkiye'de tarım sektöründe yaşanan değişimi bir başka deyişle küçülmenin nedenlerini gözler önüne sermektedir.

Türkiye'de ise kırsal kesimdeki nüfusun genelde eğitim düzeyi düşük, yaşı orta yaşın üzerinde olan kırdan kente göç etmeyi zorunlu olmadıkça tercih etmeyen bireylerden oluştuğu bilinmektedir. Türkiye'de tarımda yaşanan sorunlar şu şekilde özetlenebilir (Sayın, 2017): İşletmelerin büyük çoğunluğu küçük ve işletme arazisi parçalı yapıdadır. $\mathrm{Bu}$ durum, işletme gelirini ve işletmeler arası gelir dağılımını olumsuz etkilemektedir. Kırsal alandaki yoğun nüfus baskısı ve yasal yetersizlikler parçalanmayı teşvik etmektedir. Tarımda üretici örgütlenmesi ve finansman olanakları beklenen düzeyde değildir, diğer yandan istihdam edilenlerin gelir düzeyi diğer sektörlere göre düşük kalmaktadır. Kırsal nüfus yoğunluğu fazla, kırsal nüfusun eğitim düzeyi kente göre düşük, yeni teknoloji kullanım olanakları sınırlı, hammaddesi dış alımla sağlanan tarımsal girdilerin fiyatları artış eğiliminde, tarımda hem ürün sigortası hem de üretici sosyal güvenliği istenen düzey değildir.

Küresel anlamda ise $\mathrm{AB}$ ve $\mathrm{ABD}$ 'de verilen destekler kırsal kalkınma, sürdürülebilir tarım olmak üzere yalnızca üretim aşamasına değil hasat sonrasını da içeren yatırımlara yönelik iken Türkiye'de verilen desteklerin doğrudan destekler ekseninde yoğunlaştığ görülmektedir. OECD'nin 2018 yılı Tarım Raporu'nda Türkiye'de tarıma doğrudan verilen desteklerin OECD ortalamasından fazla olduğunun altı çizilmektedir. Raporda "ticareti en çok bozucu" desteklerden biri olarak değerlendirilen piyasa fiyat desteğinin baskın bir ağırlığa sahip olmasının ise üreticilerin nakit destek ödemelerine olan bağımlılığına işaret ettiği ifade edilmektedir. OECD, piyasa fiyat desteği yerine çevreyi ve doğayı koruyarak sürdürülebilir ve verimli üretim çerçevesinde üreticilerin eğitimi, yenilikler ve tarımsal altyapı projelerine ağırlık verilmesini önermektedir (OECD, 2018).

\section{Tarımda Kalma Eğilimini Etkileyen Başlıca Faktörler}

Tarım sektörü, etkisi azalmasına rağmen halen iş gücü ve beslenmeye etkisi, sanyi sektörüne sağladığı hammadde, milli gelire katkısı bakımından önemli olma özelliğini korumaktadır. Ancak gelinen noktada, taşıdığı bu öneme karşın, tarımda giderek yaşlanan ve tarım dışına kayan bir üretici sorunu yaşanmaktadır. Tarımsal üretimin devamlılığın sağlanması emek, toprak, sermaye ve girişimciden oluşan üretim faktörlerinin ücret, rant, faiz ve kar getirisi açısıdan etkin ve verimli olmasına bağlıdır. Bu araçlardan birinde meydana gelebilecek getiri düşüşü tarımsal üretimin sürdürülebilirliğini negatif yönde etkilemektedir. Üreticilerin "tarımda kalma" ya da "kalmama" eğilimlerine neden olan temel faktörlerin doğru belirlenmesi; geleceğe yönelik gida güvencesi ve tarımın sürdürülebilirliğinin sağlanması, kırsal alanların sosyo-ekonomik devamlılığının sağlanması açısından son derece önemli görülmektedir.

Literatüre göre üretici kararları ve davranışları ekonomik, sosyal, kültürel, politik, coğrafi ve psikolojik olmak üzere oldukça çeşitli faktörlerden etkilenmektedir. Ekonomik açıdan üreticileri tarımda kalmaya teşvik eden olumlu faktörlerden bazıları aşağıda sıralanmaktadır. Tarımsal faaliyeti sürdürülebilirliği açısıdan iyi ve sürekli bir gelir ekonomik açıdan olumlu faktörler arasında yer alırken ürün fiyatındaki dalgalanmalar tarımda kalma eğilimini olumsuz yönde etkilemektedir (Çizelge 2)

Sosyal ve kişisel açıdan tarımda kalmayı etkileyen faktörlerden bazıları aşağıda sıralanmaktadır. Çiftçiliği sevmek tarımsal faaliyeti sürdürmeye olumlu katkıda bulunurken üreticinin çocuklarını köyde büyütmek istememesi olumsuz faktör olarak ifade edilmektedir (Çizelge 3).

Fiziksel açıdan üreticilerin tarımda kalmasını etkileyen faktörlerden bazıları aşağıda sıralanmaktadır. Arazi yapısının uygunluğu fiziki kapsamda olumlu bir faktörken yetersiz arazi büyüklüğü ise olumsuz bir faktör olarak ortaya çıkmaktadır (Çizelge 4).

Üreticilerin tarımsal faaliyetlerini sürdürmelerine etki eden politika faktörlerinden bazıları aşağıda sıralanmaktadır. Tarımda kalıp kalmama durumunda destekleme tutarindan memnun olma pozitif bir politika faktörüyken vergilerin yüksek olması negatif bir politika faktörüdür (Çizelge 5).

\section{SONUÇ ve ÖNERİLER}

Genel olarak her ülke gida güvenliği ile gıda güvencesini sağlamak, tarımsal ürün ticaretinde bulunmak ve kırsal alanda yaşayanların memnuniyetini sağlayarak onları yerinde tutmak amacıyla tarıma destek vermektedir. Makroekonomik göstergeler çerçevesinde Türkiye'de uygulanan tarımsal desteklerin ve izlenen politikaların genel olarak üreticileri tarımsal üretimde tutmada yeterli olduğu söylenemez. . 
Çizelge 2. Kalma eğilimini etkileyen başlıca ekonomik faktörler

\begin{tabular}{|c|c|}
\hline Olumlu Faktörler & Olumsuz Faktörler \\
\hline - İyi bir gelir sağlamak & - Mecburiyet, başka iş olmaması \\
\hline - Talep artışı & - Ürün fiyatında dalgalanmalar \\
\hline - Sürekli bir gelir sağlamak & - Tarım dışı yatırımlara sahip olmak \\
\hline - Hayat standardını yükseltmek & - Ülke ekonomisini stabil görmemek \\
\hline Ailenin besin ihtiyacı & - Borçlar \\
\hline - Parayı değerlendirmek & - Faiz oranlarının stabil olmaması \\
\hline - Aile işgücünü değerlendirmek & - İşletme kayıtlarının tutulmaması \\
\hline - İhracat yapmak & - Üretimden pazara kadar aracıların çok olması \\
\hline - İyi fiyata ürünleri satmak & - Maaşlı sabit bir iş garantisi istemek \\
\hline - Arz devamlilığ & - Girdi masraflarının fazla olması \\
\hline - İşletmenini mevcut kapasitesinin yeterli olması & - İşçilik masraflarının fazla olması \\
\hline $\begin{array}{l}\text { - İşcilik ve işçi hizmetlerinden (bakım, idare, takip vb) } \\
\text { memnum olmak }\end{array}$ & - Teknik bilgiye erişmenin zor olması \\
\hline $\begin{array}{l}\text { İlaç, tohum ve gübreleri istenen zaman, fiyat ve } \\
\text { miktarda bulmak }\end{array}$ & $\begin{array}{l}\text { Hastalık ve zararlılarla mücadelenin zor } \\
\text { olması }\end{array}$ \\
\hline Alet ve makinayı kolay temin etmek & - Yabancı işgücü bulmada güçlükler \\
\hline - Ürünün pazarlanmasının kolay olması & - Hırsızlık olayları \\
\hline Kolay ve hızlı nakliye alt yapısı & - Yangın nedeniyle ürününü zarar görmesi \\
\hline - Talebin sürekli olması & - Pazar garantisi olmaması \\
\hline - Depolama kolaylığı & - Ürün veriminde değişiklikler \\
\hline - Yetiştiriciliğinin kolay olması vs. & • İşçilerin sağlık sorunları olması vs. \\
\hline
\end{tabular}

Kaynak: "Kalma Eğilimi Araştırması" ön bulguları (Doktora Tezi), 2018.

Çizelge 3. Kalma eğilimini etkileyen başlıca sosyolojik, kültürel ve kişisel faktörler

\section{Olumlu Faktörler}

- Baba mesleği olması

- Çiftçiliği sevmek

- Zamanı değerlendirmek

- Ailede bu işi yapacak başka kişi olmaması

- Ziraat mühendisi olmak

- Başka iş yapmayı bilmemek

- Bu işte risk ve belirsizliğin düşük olması

- Ailede tüm kardeşlerin bu işte çalışması

- Köyde yaşamayı sevmek vs.

Kaynak: "Kalma Eğilimi Araştırması” ön bulguları (Doktora Tezi), 2018.

Çizelge 4. Kalma eğilimini etkileyen başlıca coğrafi, kırsal altyapı ve fiziksel faktörler

\section{Olumlu Faktörler}

- Arazinin yapılan tarıma uygun olması

- Yeterli arazi büyüklüğü olması

- Uygun iklim koşulları

- Uygun coğrafi koşullar

- Uygun ulaşım altyapısı vs.

Kaynak: "Kalma Eğilimi Araştırması” ön bulguları (Doktora Tezi), 2018.

Çizelge 5. Kalma eğilimini etkileyen başlıca tarımsal politika faktörleri

\begin{tabular}{l}
\hline Olumlu Faktörler \\
Uygun prim verilmesi \\
- Destedinin kolay bulunması \\
\hline İhracat desteği olması \\
\hline Üye birliğin hizmetlerinden memnun olmak \\
\hline İlgili Bakanlık politikalarından memnun olmak vs.
\end{tabular}

Olumsuz Faktörler

- Sosyal güvenlik ödemelerini yüksek bulmak

- Vergileri yüksek bulmak

- Desteklemeleri yetersiz bulmak

- Alım garantisinin olmaması vs.

Kaynak: "Kalma Eğilimi Araştırması” ön bulguları (Doktora Tezi), 2018 
Tarımsal etkinliği sağlamak ve tarımı cazibe merkezi haline dönüştürmek için Türkiye'de üretim yanında teknoloji odaklı ve katma değer yaratacak politikaların uygulanmaya başlanması gereksinimi vardır. Özellikle girdi maliyetlerinin azaltılması ve ölçek ekonomisine geçilerek ihracat potansiyeli ve katma değeri yüksek olan ürünlerin üretilmesi, tarım sektöründeki kar ve gelirin artırılması ile tarım sektörünün vazgeçilmez bir üretim kolu olması sağlanabilir. Aksi takdirde uygulanan mevcut destekler çerçevesinde genç nüfusa eğitim verilse dahi söz konusu gençlerin bu sektöre yönlendirilmesi zor olabilir.

Tarım sektöründe istikrarı sağlamak adına yurtiçi ve yurtdışı piyasa araştırmalarına göre talebe dayanan planlı üretim modeline geçilmesi, üretici mağduriyetini önleyecektir. Üretici örgütleri başta olmak üzere özel sektörle işbirliği içinde üretim ve satış kanallarında güçlü bir kurumsal yapı oluşturulmalıdır. Tarımda kalma eğilimini artırmak üzere kırsal alandaki iş ve yaşam şartları cezbedici hale getirilebilir, belirlenecek özellikte ve miktarda üretim yapacağını garantileyen genç çiftçilere her ay asgari ücret verilebilir, gençlere ve kadınlara pozitif ayrımcılık yapan finansal destek çözümleri yaygınlaştırılabilir ve onlara yönelik eğitimler verilebilir, kooperatifleşme ve üretici birlikleri kurulması özendirilebilir. Tarıma yeniden dönmek isteyen nüfusa yönelik tarımda ihtiyaç duyulan alanları kapsayıcı bilgilendirme yapılıp teşvik programları sunulabilir. Sonuç olarak tarımsal sürdürülebilirliği ve üreticilerin üretimde kalmasını sağlamak adına tarımsal destekler, girdi desteği şeklinde değil de etkin bir fiyat ve piyasa mekanizmasının kurulması için verilmelidir.

Üretici kararlarının ve davranışlarının; ekonomik, sosyal, kültürel, politik, coğrafi ve psikolojik olmak üzere oldukça çeşitli faktörlerden etkilendiği bilinmektedir. Nitekim günümüzde yaygın iletişim ve bilgi ağları nedeniyle üreticiler ekonomik kazanım sağlayacak tüm faaliyet alanlarını yakından izlemekte ve alternatif çalışma alanları üzerinde daha fazla bilgiye sahip bulunmaktadırlar. Dolayısıyla üreticilerin tarımda kalmalarını sağlayan en önemli faktör ekonomik kazanım öne çıkmakla birlikte sosyolojik, psikolojik, kültürel, kişisel, politik ve diğer pek çok faktör de bu durumu olumlu ya da olumsuz olarak etkileyebilmektedir. Bu nedenle anılan ana ve alt faktörler dikkate alınarak, üreticilerin tarımdan ayrılma sebepleri veya kalma gerekçelerinin düzenli olarak araştırılarak, kalma eğilimini artıracak yeni çözüm yolları oluşturulması, tarımsal üretimde yeterlilik ve sürdürülebilirlik açısından önemli bir adım olacaktır.

\section{TEŞEKKÜR}

$\mathrm{Bu}$ çalışmada Akdeniz Üniversitesi Bilimsel Araştırma Projeleri Koordinasyon Merkezi (BAP) tarafindan desteklenen FDK-2018-3768 no'lu " Antalya İlinde Üreticilerin Tarımda Kalma Eğilimi ve Etkileyen Faktörlerin Analizi " başlıklı Doktora Tez Projesi kapsamında elde edilen ön bulgular kullanılmıştır. Bu araştırmaya FDK-2018-3768 no'lu proje çerçevesinde destek sağlayan Akdeniz Üniversitesi Bilimsel Araştırma Projeleri Koordinasyon Merkezi'ne (BAP) teşekkür ederiz.

\section{KAYNAKLAR}

Anonim 2017a. Avrupa Birliği Ortak Tarım Politikası. https://ec.europa.eu/agriculture/cap-funding/young -farmers_en (Erişim tarihi: 05.04. 2018).

Anonim 2018a. http://www.businessankara.com/ ekonomi-haberleri/2017-turkiye-tarimsal-

desteklemeler 'saha- arastirmasi- sonuclariaciklandi. html. (Erişim tarihi: 05.08.2018).

Arlı R, Balcı M, Abay C 2014. Gençlerin Kırsalda Çiftçilik Yapma Eğilimleri: Akhisar İlçesi Örneği, Ulusal Aile Çiftçiliği Sempozyumu, 30-31 Ekim 2014, Ankara.

Ataseven Y 2016. Türkiye'de Tarımsal Destekleme Politikaları: Genel Bakış ve Güncel Değerlendirmeler.https://www.researchgate.net/pu blication/312918415_Turkiye'de_Tarimsal_Destekl eme_Politikalari_Genel_Bakis_ve_Guncel_Degerle ndirmeler (Erişim tarihi: 09.08.2018).

Bezu S, Holden S 2014. Are Rural Youth in Ethiopia Abandoning Agriculture. World Development Vol. 64, pp. 259-272, 2014 0305-750X/_ 2014 The Authors. Published by Elsevier Ltd.

Cengiz S, Baydur CM 2010. Kırdan Kente Göç ve Tarımsal Verimlilik: Türkiye Örneği. Ç.Ü. Sosyal Bilimler Enstitüsü Dergisi, 19(2): 85 - 98

Çelik Z 2017. Samsun İli Çarşamba İlçesinde Aile Çiftçiliğinin Mevcut Durumu, Sorunları ve Sürdürülebilirliği. Ondokuz Mayıs Üniversitesi. Tarım Ekonomisi Anabilim Dalı. Yüksek Lisans Tezi. $63 \mathrm{~s}$.

Çukur T 2016. Milas İlçesinde Süt Sığırcılığı Yapan Çiftçilerin Tarımda Kalma Eğilimlerinin Belirlenmesi. XII. Ulusal Tarım Ekonomisi Kongresi. 25-27 Mayıs 2016. Isparta.

Çukur T, Işın F 2008. İzmir İli Torbalı İlçesinde Sanayi Domatesi Üreticilerinin Tarımın Çok Fonksiyonluluğu Kavramına Bakış Açıları. Ege 
Üniversitesi. Ziraat Fakültesi Dergisi. 2008, 45 (3): 185-193 ISSN 1018 - 8851.

Fidan F 2017. Bartın İlinde Organik Tarımın Ekonomik Boyutu. Bartın Üniversitesi Sosyal Bilimler Enstitüsü İktisat Anabilim Dalı. Yüksek Lisans Tezi. $167 \mathrm{~s}$.

Gürbüz M, Karabulut M 2008. Kırsal Göçler İle SosyoEkonomik Özellikler Arasındaki İlişkilerin Analizi. Türk Coğrafya Dergisi, 50:37-60.

Sayın C 2003. Türkiye'de Tarımsal Destekleme Politikaları. Türkiye Odalar ve Borsalar Birliği Yayınları. Ankara.

Sayın C 2017. Tarım Politikası Ders Notları.

OECD 2018. https://www.oecd-library.org/agricultureand-food/agricultural- policy- monitoring- andevaluation-2018/ turkey_ agr_ pol-2018-27-en (Erişim tarihi : 02.08.2018).

TOB 2018. Tarım ve Orman Bakanlığı. https://www.tarimorman.gov.tr/ (Erişim tarihi: 19.08.2018).
TÜİK 2018. Tarımsal İşletme Yapı Araştırması,. http://www.tuik.gov.tr/VeriBilgi. do?alt_id $=1003$. (Erişim: 15.08.2018).

Karahan Uysal Ö 2015. Manisa İli Yunt Dağı Köylerinde Çiftçilerin Tarımsal Üretime Yaklaşımlarını Etkileyen Faktörlerin Analizi. Sosyal ve Beşeri Bilimler Araştırmaları Dergisi. Journal of Social Sciences and Humanities Researches. 1(35): 73-95.

Yalçın GE, Kara FÖ 2016. Kırsal Göç ve Tarımsal Üretime Etkileri. Harran Tarım ve Gıda Bilimleri Dergisi, 20(2): 154-158.

Yavuz GG, Özüdoğru T 2015. Türkiye'de Tahıl Üreticilerinin Tarımsal Amaçları ve Üretimleri. https://www.avekon.org/papers/1341.pdf. Session: 4B Tarım Ekonomisi (Erişim: 12.12.2017).

Yıldız Ö 2015. Ege Bölgesi’nde Sürdürülebilir Tarıma Tarımsal Yayımın Katkısı ve Üretici Eğilimleri. Ege Üniversitesi, Fen Bilimleri Enstitüsü, Tarım Ekonomisi Anabilim Dalı, Doktora Tezi, 169 s. 